Article

\title{
Investigation of the Factors Affecting Artificial Seed Sowing Success and Seedling Survival in Pinus brutia Natural Stands in Middle Elevations of Central Cyprus
}

\author{
Petros Petrou ${ }^{1}$ and Elias Milios ${ }^{2, *}$ \\ 1 Department of Forests, Ministry of Agriculture, Rural Development and Environment, Nicosia 1414, Cyprus; \\ pepetrou@fd.moa.gov.cy \\ 2 Department of Forestry and Management of the Environment and Natural Resources, \\ Democritus University of Thrace, Pantazidou 193, 68200 Orestiada, Greece \\ * Correspondence: emilios@fmenr.duth.gr
}

Received: 28 October 2020; Accepted: 15 December 2020; Published: 17 December 2020

\begin{abstract}
The aim of this study was to analyze the germination of Pinus brutia Ten. seeds, in the field, in relation to factors such as period of sowing, light environment, and watering, in sites of different productivity in the middle elevations in central Cyprus. Two sowing experiments were conducted in three sites of different productivity. In the first experiment $P$. brutia seed sowing took place in February 2009 in two sowing environments which were gap and under canopy environments. The shade conditions in those environments were determined using hemispherical photographs. Also, the influence of watering on the seed germination was checked. In the second experiment, which was established in the same areas as in the first experiment, the seed sowing took place in December 2009. However, in this case, no watering was applied during the germination period. Moreover, the survival of the seedlings from both sowing periods were monitored up to the end of 2010. During the period of monitoring, the influence of watering was checked. The germination rates of seeds from the February sowing were very low. On the contrary, from the December sowing, the germination rates of seeds were very high in both sowing environments in all studied sites. In the case of seedling survival from the February and December sowing, mortality rates were relatively high in all sites except from the under-canopy sowing environment where watering was applied in the medium productivity site. From the December sowing, from a practical point of view, the number of survived seedlings, in all the plots of the three sites can be considered adequate for the successful regeneration of $P$. brutia.
\end{abstract}

Keywords: Cyprus; Pinus brutia; sowing; facilitation; seedling survival

\section{Introduction}

Pinus brutia Ten. is abundant throughout the Eastern Mediterranean area as it is a characteristic species of that region [1-3]. It is widespread in Cyprus, accounting $90 \%$ of the island total forest area, covering 175,000 ha [4-6]. The population of P. brutia in Cyprus is peripheral and is characterized with high genetic diversity, consisted of different sub-populations [7]. It is a tree of great economic and ecological importance for the country $[5,6,8]$. In Greece, it is one of the pine species that has been used in reforestations of peri-urban forests [9-11].

Pinus brutia is a light demanding, fast growing and site insensitive tree species that can grow in most soil types [3,12]. It is a well-adapted species to semi-arid conditions of the Mediterranean area [13]. The short juvenile phase of the species [14] justifies the fact that its flowering can begin in the second 
year and a normal cone development has been observed in 7-year-old trees [15]. However, Boydak [12] based in an old bibliography states that a normal cone development has been observed even in 4-year-old trees. Pinus brutia is an obligate seeder, therefore the regeneration of this species is totally dependent upon seedling recruitment [16,17].

In many cases, the occurrence of P. brutia regeneration is not adequate, mainly due to the harsh environmental conditions of the growing season in Cyprus [18,19].

In lower and middle elevations of Cyprus, only in few cases, dense or rather dense young P. brutia formations established in open areas (in bare ground) are observed (personal observations). Petrou and Milios [19], in middle elevations of central Cyprus found that in open areas (bare ground) all the newly established seedlings had died by the end of the first growing season. On the other hand, they refer that nurse plants such as P. brutia trees and low shrubs facilitate the establishment and the survival of P. brutia seedlings. In that context, they recommend the use of facilitation process in the silvicultural treatments of $P$. brutia forests in Cyprus.

According to Thanos [20], P. brutia displays a variable attribute in seed germination regarding timing of seedling emergence depending on the altitude and latitude of the provenance. Generally, if the climatic conditions are suitable, the seeds of $P$. brutia germinate throughout the rainy season $[16,21]$.

Facilitation in plant communities is related to creation of favorable micro-habitats by the benefactor plant(s) and thus a great research interest has emerged regarding determination of the specific facilitative processes [22-25]. However, in harsh environments where regeneration of the dominant species is problematic, research regarding practical measures for the preservation of the existent vegetation is necessary. In this effort, facilitation process can be used as a tool in the development of applied techniques that can be used for the amelioration of the harsh conditions that the newly establish plants confront (see [26]). These techniques can be incorporated in the forestry practice of regions that are or will be under the threat of ecosystem degradation as a result of climate change [26]. Cyprus is a such case, and particular P. brutia formations in the middle elevations of central Cyprus.

In various forest species, most studies of seed germination and of the factors that influence it, are conducted in controlled environment in laboratories and in nurseries [27]. The same has been observed in P. brutia studies since all the relevant studies were taken place in nurseries and in laboratories (e.g., [28-31]).

Based on the results of the aforementioned studies treatments for the best seedling production in nurseries are mainly proposed, while in some cases measures for a successful sowing in the field are recommended. On the contrary, in the present study, the germination of P. brutia seeds in the field was investigated.

The acquired information can be incorporated in the future treatments for the regeneration of harsh sites with P. brutia. The aim of this study was to analyze the germination of P. brutia seeds, in the field, in relation to factors such as period-season of sowing, light environment, and watering in sites of different productivity in the middle elevations in central Cyprus. The acquired knowledge can be the first step upon which silvicultural treatments can be based in order to successfully regenerate P. brutia formations using the facilitation process.

\section{Materials and Methods}

\subsection{Study Site}

The study was conducted in middle elevation (320-650 $\mathrm{m}$ a.s.1.) forest areas in central Cyprus $\left(34^{\circ} 53-34^{\circ} 58 \mathrm{~N}, 33^{\circ} 13-33^{\circ} 21 \mathrm{E}\right)$. According to the air temperature and rainfall data (for 1991-2000) obtained at the closest meteorological station (Kornos, $34^{\circ} 55 \mathrm{~N}, 33^{\circ} 24 \mathrm{E}, 370 \mathrm{~m}$ a.s.l.), were both rainfall and temperature data are recorded, the annual rainfall is $477.1 \mathrm{~mm}$ and the mean yearly temperature is $18.4{ }^{\circ} \mathrm{C}$. In Figure 1, the monthly rainfall data during the years 2009 and 2010 of the meteorological station of Lythrodontas forest station is presented. This meteorological station is located within the study area, very close to the experimental sites. The geological substrate of the study area belongs to 
volcanic sequence diabase dykes with pillow lava screens [32]. The soil texture is sandy loam to sandy clay loam, while the soil $\mathrm{pH}$ ranges from slightly acidic to slightly alkaline [33].

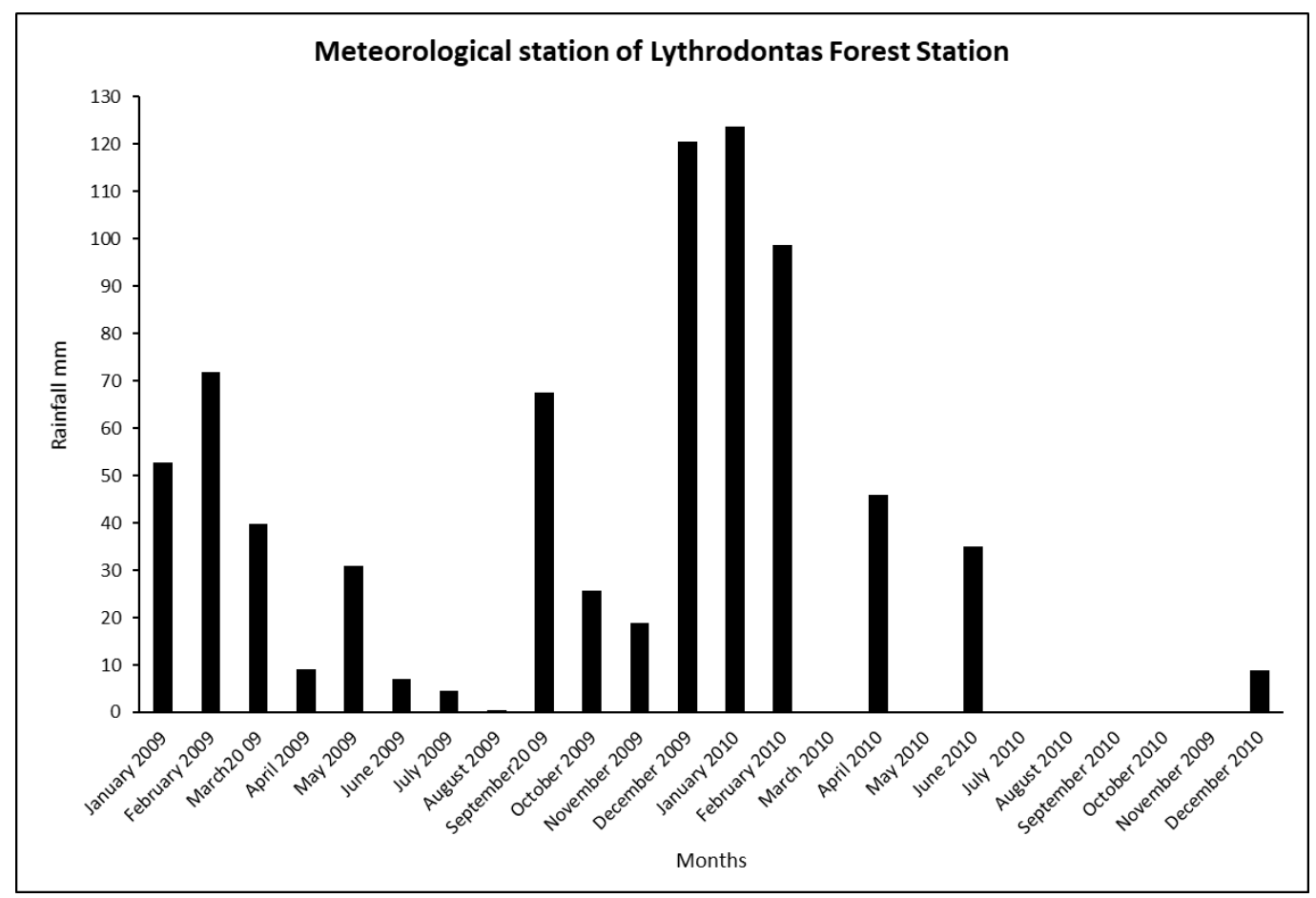

Figure 1. Monthly rainfall data from January 2009 to December 2010 obtained from the meteorological station of the Lythrodontas Forest Station.

The study area in the past consisted mainly of vine and olive yards. Those fields were abandoned during the last century. Nowadays the area has been recolonized mainly by P. brutia trees which is the dominant species in the area. Under the P. brutia trees and in the interspaces, shrubs-such as Pistcia lentiscus, P. terebinthus, Cistus creticus, C. salvifolius, Thymus capitatus, Lavandula stoechas, Olea europaea, Callicodome villosa, etc.-are found.

\subsection{Experimental Design}

\subsubsection{Site Selection}

In the wider study area, Petrou [33] distinguished three categories of sites for P. brutia formations according their productivity: good productivity sites, medium productivity sites and bad productivity sites. The site characterization was based on soil depth [34-38] and on the height growth of dominant and codominant trees [39]. For the soil depth determination, soil profiles were used and for the height growth determination the mean annual increment (the ratio of the total height to the total age of the tree) [40] of dominant or codominant P. brutia trees was used. For the determination of the mean annual increment, cores from stump height were used [33]. According to Petrou [33] the soil depth in good productivity sites is over $100 \mathrm{~cm}$, in medium productivity sites is approximately $40-80 \mathrm{~cm}$ and in bad productivity sites is approximately $15-30 \mathrm{~cm}$.

In the frame of the present study, three sites were selected. One site was of good productivity called site A ( $34^{\circ} 56 \mathrm{~N}, 33^{\circ} 14 \mathrm{E}, 575 \mathrm{~m}$ a.s.l. slope: $0-10 \%$ ), one of medium productivity called site B ( $34^{\circ} 55 \mathrm{~N}, 33^{\circ} 20 \mathrm{E}, 320 \mathrm{~m}$ a.s.l. slope: $\left.0-10 \%\right)$ and one of bad productivity called site C ( $34^{\circ} 57 \mathrm{~N}$, $33^{\circ} 17 \mathrm{E}, 460 \mathrm{~m}$ a.s.l. slope: $0-20 \%$ ). The canopy cover of these sites was below $75 \%$. In each of the sites, in the formations of P. brutia there are rather dense groups of trees (which create shade beneath them) that alternate with small or medium size gaps. Each site occupies a continuous area of 5 ha, apart site A 
which is comprised by two areas (of 3 and 2 ha, respectively) since in good productivity sites there are not continuous areas of 5 ha with $P$. brutia formation having canopy cover that is below $75 \%$. The soil depth in the wider area of each of the aforementioned sites was in agreement with the soil depth range of the site productivity category in which each site was classified. Moreover, based on the mean annual increment of dominant and codominant trees growing in the wider area of each one of the three sites $(A, B, C)$ their classification to the site productivity categories was also verified by the site index curves created for central Cyprus by Kitikidou et al. [8].

\subsubsection{Experiment Establishment-Germination Measurements}

In February 2009, 144 permanent plots of $6 \mathrm{~m}^{2}(3 \times 2 \mathrm{~m})$, were established at random (48 plots in each site). The 72 plots were established randomly under the canopy of the groups of $P$. brutia trees ( 24 plots in each site) and the other 72 plots were established randomly in the canopy gaps with small or medium size (24 plots in each site). Within each plot the shrubs, the herbaceous plants and the dead biomass were removed. Additionally, all plots were protected from grazing by goats, with a fence $1.5 \mathrm{~m}$ high.

In order to determine the light environment of each plot, hemispherical photograph was taken at $1.5 \mathrm{~m}$ high from the center of each plot using a horizontally-leveled digital camera (Nikon Coolpix 900 digital camera having fisheye lens). All photographs were taken before sunrise or after sunset having a clear sky. The photos were analyzed using Hemiview canopy analysis software ver. 2.1 [41]. Visible sky (or canopy openness, or gap fraction) is the amount of the sky that is visible as a proportion of the entire hemisphere when it is observed from a single point [42]. Visible sky (Vs) is related to the light attain a point $[42,43]$. A value of 1 in Vs means that the whole sky is visible while when the Vs takes a value of 0 this means that the whole sky is blocked.

Each one of the plots was divided in two equal parts of $3 \mathrm{~m}^{2}\left(3 \mathrm{~m}^{2}, 2 \times 1.5 \mathrm{~m}\right)$. The treatments of the present study were applied in one of the parts of each plot. The second part of the plots was occupied by planted seedlings (unpublished data). At the end of February 2009, 36 seeds of P. brutia were sown (Late Sowing Period $=$ LSP) at $0.5 \mathrm{~cm}$ depth in the soil with $15 \mathrm{~cm}$ distance between individual seeds in each plot. All the points of sowing were marked and numbered. In the half plots (12 under the canopy and 12 in the gaps, in each site) apart from the natural water supply (rain) supplemental water $\left(15 \mathrm{~L} / 3 \mathrm{~m}^{2}\right)$ was added at the time of sowing and every fifteen days for two months. In the other half plots (12 under the canopy and 12 in the gaps, in each site), no water supplementation treatment was applied. During the germination of seeds in LSP (April-mid May 2009), in April 2009 the rainfall was $9.1 \mathrm{~mm}$, while in May 2010 was $30.9 \mathrm{~mm}$ (Figure 1). At the middle of May 2009, when the seed germination was completed, the total number of germinated seeds was counted in each plot. Externally, germination was marked by the bursting of the testa and the extrusion of the plumule ([44]).

The above treatments were repeated (in the same plots) in December 2009 (Early Sowing Period = ESP). In particular, the same plots, as in the LSP experiment, were used and the same number of seeds, using the same distance between individual seeds, was sown (at $0.5 \mathrm{~cm}$ depth) in each plot. In this case, no water supplementation treatment was applied in the plots. The plots received only the natural water from the rainfalls. Therefore, in ESP, in each site, 24 plots were under the canopy of the groups of $P$. brutia trees and 24 plots were in the canopy gaps. During the germination of seeds in ESP (late February-March 2010) in February 2010 the rainfall was 98.7 mm, while in March 2010 was $0 \mathrm{~mm}$ (Figure 1). At the beginning of April 2010, when the seed germination was completed, the total number of germinated seeds was counted in each plot.

The seeds used in this experiment were obtained from the Cyprus Department of Forests and they had been collected randomly from the wider study area, which covers 14,000 ha and is located in middle elevation forest areas in central Cyprus. Throughout the experimentation period, seeds were stored in a refrigerator $\left(3-5^{\circ} \mathrm{C}\right)$ in darkness. Before the experiment, damaged, insect-infected, and empty seeds were discarded and eliminated. 
During the two periods of seeds germination (LSP in April-mid May 2009, ESP in late February-March 2010) measurements of (maximum) surface soil temperature were taken, in all plots. Those measurements were carried out at the beginning, the middle and the end of above-mentioned periods. All measurements were taken at $0.5 \mathrm{~cm}$ depth from 13:00-15:00 by a soil thermometer sensor with an accuracy of $0.1^{\circ} \mathrm{C}$.

The data collection scheme of the density of the germinated seeds, regarding the LSP treatment is considered to apply to the following experimental design: The plot of $2 \times 1.5 \mathrm{~m}$ is considered as the experimental unit. The design includes two factors between the experimental units. In particular these factors are: (a) the "sowing environment" with two levels: gap (G) and under canopy (UC), and (b) the "water supplementation" with two levels, water supplementation-watering (W+) and no water supplementation (W-).

\subsubsection{Surviving Measurements}

In the plots where water supplementation was applied in the sowing that took place at the end of February 2009 the watering was continued (in the same quantity) every 15 days up to the end of October 2009 and it was repeated within the same interval from April 2010 up to the end of October 2010. Moreover, the established seedlings from both periods of seed germination (LSP in April-mid May 2009, ESP in late February-March 2010) were monitored until December 2010. Their density was recorded in each plot at the end of each month.

The data collection scheme of seedlings that were established in the ESP and survived up to December 2010 is considered to apply to the following experimental design: The plot of $2 \times 1.5 \mathrm{~m}$ is considered as the experimental unit. The design includes two factors between the experimental units. In particular these factors are: (a) the "sowing environment" with two levels: gap (G) and under canopy (UC), and (b) the "water supplementation" with two levels, water supplementation-watering $(\mathrm{W}+)$ and no water supplementation (W-).

\subsection{Statistical Analysis}

The data of germinated seed density after the LSP and the data of seedlings that were established in the ESP and survived up to December 2010 were analyzed using the ANOVA method $[45,46]$ in the frame of the general linear models (GLM). The comparisons were made using the Bonferroni Test $[47,48]$. The general linear model that corresponds our experimental design includes: (1) the main effects of the two factors "sowing position" and "water supplementation", and (2) the interaction of the two factors.

In regard to the ESP treatment the comparisons of the germinated seeds densities between the two sowing environments (G-gap and UC-under canopy) were carried out using the $t$-test and the Mann-Whitney test. All statistical analyses were carried out for each site separately, using the SPSS 12.0 package [49].

\section{Results}

\subsection{Visible Sky-Light Conditions}

In all sites the highest value of Vs in the photographs that were taken in a plot that was established in the sowing environment "under the canopy" (UC) was lower than the lowest of Vs in the photographs that were taken in the plots that were established in the sowing environment "gap" (G) (Table 1). 
Table 1. Visible sky values in the plots of each of the two factor (sowing environment and water supplementation) level combinations in each of the three sites.

\begin{tabular}{ccccccc}
\hline \multirow{2}{*}{ Site Combinations of the Two Factor Levels } & \multicolumn{5}{c}{ Visible Sky (Vs) } \\
\cline { 3 - 7 } & & Mean & SD & Min & Max & $n$ \\
\hline \multirow{3}{*}{ A } & UC and W- & 0.167 & 0.006 & 0.156 & 0.176 & 12 \\
& G and W- & 0.304 & 0.013 & 0.281 & 0.333 & 12 \\
& UC and W+ & 0.175 & 0.010 & 0.157 & 0.184 & 12 \\
G and W+ & 0.312 & 0.013 & 0.293 & 0.333 & 12 \\
\hline \multirow{3}{*}{$B$} & UC and W- & 0.278 & 0.019 & 0.236 & 0.298 & 12 \\
& G and W- & 0.434 & 0.018 & 0.408 & 0.463 & 12 \\
& UC and W+ & 0.275 & 0.017 & 0.243 & 0.298 & 12 \\
G and W+ & 0.423 & 0.022 & 0.404 & 0.466 & 12 \\
\hline \multirow{3}{*}{$\mathrm{C}$} & UC and W- & 0.221 & 0.014 & 0.208 & 0.252 & 12 \\
& G and W- & 0.525 & 0.018 & 0.499 & 0.550 & 12 \\
& UC and W+ & 0.229 & 0.020 & 0.202 & 0.255 & 12 \\
\hline
\end{tabular}

$n=$ number of photos.

In each site, the mean Vs value of photos that were taken in the plots, which were established under canopy, was about the same either in these plots where water supplementation was applied ( $\mathrm{UC}$ and $\mathrm{W}+$ ) and in those where no water supplementation was taken place (UC and $\mathrm{W}-$ ). The same pattern was observed in the case of plots that were established in gap sowing environment. The mean Vs value in the plots where watering was taken place ( $\mathrm{G}$ and $\mathrm{W}+$ ) was about the same with that in plots where no water supplementation was applied ( $\mathrm{G}$ and $\mathrm{W}-$ ) (Table 1).

\subsection{Experiment Establishment-Germination Measurements}

The ANOVA analysis regarding the main effects and the interaction of the two factors, for the LSP (late sowing period) experiment in each site, presented the following: (1) for the site A (site of good productivity) (a) the factor "sowing environment" $(F(1,44)=7.283, p=0.010$ ) has a statistically significant influence on the density of the germinated seeds, (b) the factor "water supplementation" $(F(1,44)=0.773, p=0.384)$, and (c) the interaction of "sowing environment" $\times$ "water supplementation" $(F(1,44)=0.111, p=0.740)$ have no statistically significant influence on the density of the germinated seeds. (2) For the site B (site of medium productivity) (a) the factor "sowing environment" $(F(1,44)=10.196, p=0.003)$ has a statistically significant influence on germinated seeds density, (b) the factor "water supplementation" $(F(1,44)=0.839, p=0.365)$, and (c) the interaction of "sowing environment" $\times$ "water supplementation" $(F(1,44)=2.589, p=0.115)$ have no statistically significant influence on the density of the germinated seeds. (3) for the site $C$ (site of bad productivity) (a) the factor "sowing environment" $(F(1,44)=4.382, p=0.042)$ has a statistically significant influence on the density of the germinated seeds, (b) the factor "water supplementation" $(F(1,44)=0.005, p=0.943)$, and (c) the interaction of "sowing environment" $\times$ "water supplementation" $(F(1,44)=0.130, p=0.720)$ have no statistically significant influence on germinated seeds density. In the comparisons of the average (over the two levels of the factor "water supplementation") of density of germinated seeds the UC (under canopy) environment has a higher $(p<0.05)$ germinated seed density than the G (gap) environment. This is consistent for the three sites (Table 2). 
Table 2. Mean density of $P$. brutia germinated seeds in the late sowing period (LSP-February) in the plots that were established in the under canopy and in gap sowing environments (averaged over the two levels of the factor 'water supplementation') in each of the three sites ('sowing environment' main effect).

\begin{tabular}{|c|c|c|c|c|}
\hline \multirow{2}{*}{ Site } & \multirow{2}{*}{ Sowing Environment } & \multicolumn{3}{|c|}{ Density of $P$. brutia Germinated Seeds ( $n /$ plot) } \\
\hline & & Mean & SD & $n$ \\
\hline \multirow[b]{2}{*}{ A } & Under canopy (UC) & $7.00^{\mathrm{a}}$ & 5.150 & 24 \\
\hline & $\operatorname{Gap}(\mathrm{G})$ & $3.29^{b}$ & 4.206 & 24 \\
\hline \multirow{2}{*}{ B } & Under canopy (UC) & $9.50^{\mathrm{a}}$ & 5.853 & 24 \\
\hline & Gap $(G)$ & $4.13^{\mathrm{b}}$ & 5.988 & 24 \\
\hline \multirow{2}{*}{$\mathrm{C}$} & Under canopy (UC) & $5.42^{\mathrm{a}}$ & 4.481 & 24 \\
\hline & $\operatorname{Gap}(\mathrm{G})$ & $3.00^{b}$ & 3.257 & 24 \\
\hline
\end{tabular}

In each site means are statistically significant different, at $p<0.05$ when they share no common letter. The comparison was made using the Bonferroni test. $\mathrm{SD}=$ standard deviation, $n=$ number of plots.

In sites A and C, in the ESP (Early Sowing Period) experiment, there is no difference in the density of germinated seeds between the two sowing environments, but in site B the UC environment exhibited higher density of germinated seeds compared to the G environment (Table 3).

Table 3. Mean density of P. brutia germinated seeds in the early sowing period (ESP-December) in the plots that were established in the under canopy and in gap sowing environments in each of the three sites.

\begin{tabular}{ccccc}
\hline \multirow{2}{*}{ Site } & \multirow{2}{*}{ Sowing Environment } & \multicolumn{2}{c}{ Density of $\boldsymbol{P}$. brutia } & Germinated Seeds ( $\boldsymbol{n}$ /plot) \\
\cline { 3 - 5 } & & Mean & SD & $\boldsymbol{n}$ \\
\hline \multirow{2}{*}{ A } & Under canopy (UC) & $28.21^{\text {a }}$ & 7.301 & 24 \\
& Gap (G) & $31.21^{\text {a }}$ & 4.021 & 24 \\
\hline \multirow{2}{*}{ B } & Under canopy (UC) & $33.50^{\text {a }}$ & 5.158 & 24 \\
& Gap (G) & $30.79^{\text {b }}$ & 5.524 & 24 \\
\multirow{2}{*}{ C } & Under canopy (UC) & $33.29^{\text {a }}$ & 3.210 & 24 \\
& Gap (G) & $32.33^{\text {a }}$ & 5.427 & 24 \\
\hline
\end{tabular}

In each site means are statistically significant different, at $p<0.05$ when they share no common letter. The comparison was made using the $t$-test and the Mann-Whitney test. $\mathrm{SD}=$ standard deviation, $n=$ number of plots.

In the LSP experiment, the percentage of germinated seeds ranged from $11.69 \%$ in site $C$ to $18.92 \%$ in site B (total of all sites 14.97\%) (Table 4), while in ESP (early sowing period) experiment the corresponding range is from $82.52 \%$ in site A to $91.15 \%$ in site C (total of all sites $87.65 \%$ ) (Table 5).

Table 4. Seed germination percentages from the late sowing period (LSP-February).

\begin{tabular}{|c|c|c|c|c|}
\hline Site & Sowing Environment & \multicolumn{3}{|c|}{ Seed Germination Percentage $(\%)$} \\
\hline \multirow{2}{*}{ A } & Under canopy (UC) & 19.44 & \multirow{2}{*}{14.29} & \multirow{6}{*}{14.97} \\
\hline & $\operatorname{Gap}(\mathrm{G})$ & 9.14 & & \\
\hline \multirow{2}{*}{ B } & Under canopy (UC) & 26.39 & \multirow{2}{*}{18.92} & \\
\hline & $\operatorname{Gap}(\mathrm{G})$ & 11.46 & & \\
\hline \multirow{2}{*}{$\mathrm{C}$} & Under canopy (UC) & 15.05 & \multirow{2}{*}{11.69} & \\
\hline & $\operatorname{Gap}(\mathrm{G})$ & 8.33 & & \\
\hline
\end{tabular}


Table 5. Seed germination percentages from the early sowing period (ESP-December).

\begin{tabular}{|c|c|c|c|c|}
\hline Site & Sowing Environment & \multicolumn{3}{|c|}{ Seed Germination Percentage $(\%)$} \\
\hline \multirow{2}{*}{ A } & Under canopy (UC) & 78.36 & \multirow{2}{*}{82.52} & \multirow{6}{*}{87.65} \\
\hline & $\operatorname{Gap}(\mathrm{G})$ & 86.69 & & \\
\hline \multirow{2}{*}{ B } & Under canopy (UC) & 93.06 & \multirow{2}{*}{89.29} & \\
\hline & Gap $(G)$ & 85.53 & & \\
\hline \multirow{2}{*}{$\mathrm{C}$} & Under canopy (UC) & 92.48 & \multirow{2}{*}{91.15} & \\
\hline & Gap (G) & 89.81 & & \\
\hline
\end{tabular}

During the germination period of the LSP experiment (April-middle of May), the mean soil temperature $(0.5 \mathrm{~cm}$ depth $)$ did not overcome the $21.33^{\circ} \mathrm{C}$ in the under-canopy sowing environment, while in the gap environment the mean temperatures ranged from to 30.12 to $31.13^{\circ} \mathrm{C}$. (Table 6). On the other hand, during the germination period of the ESP experiment (end of February-March), the mean soil temperature did not overcome the $20.15^{\circ} \mathrm{C}$ in the under-canopy sowing environment, while in the gap sowing environment the mean temperatures ranged from 22.77 to $23.91{ }^{\circ} \mathrm{C}$ (Table 7).

Table 6. Soil temperature values for the period when the seed germination of LSP (April-middle of May 2009) took place in the plots of each combination of the two factor levels in each of the three sites.

\begin{tabular}{|c|c|c|c|c|c|c|}
\hline \multirow{2}{*}{ Site } & \multirow{2}{*}{ Combinations of the Two Factor Levels } & \multicolumn{5}{|c|}{ Soil Temperature $\left({ }^{\circ} \mathrm{C}\right)$} \\
\hline & & Mean & SD & Min & Max & $n$ \\
\hline \multirow{4}{*}{ A } & UC and W- & 20.47 & 1.091 & 18.6 & 22.7 & 36 \\
\hline & G and $W-$ & 30.48 & 1.843 & 27.1 & 33.6 & 36 \\
\hline & UC and $\mathrm{W}+$ & 20.35 & 1.040 & 18.2 & 22.0 & 36 \\
\hline & G and W+ & 30.12 & 1.584 & 27.1 & 32.8 & 36 \\
\hline \multirow{4}{*}{ B } & UC and W- & 21.14 & 1.476 & 18.1 & 23.7 & 36 \\
\hline & G and W- & 30.27 & 1.364 & 27.5 & 32.7 & 36 \\
\hline & $\mathrm{UC}$ and $\mathrm{W}+$ & 21.11 & 1.120 & 18.9 & 22.6 & 36 \\
\hline & G and $\mathrm{W}+$ & 30.52 & 0.996 & 28.9 & 32.7 & 36 \\
\hline \multirow{4}{*}{$\mathrm{C}$} & UC and W- & 21.08 & 1.464 & 18.9 & 23.9 & 36 \\
\hline & G and $W-$ & 30.92 & 1.422 & 28.2 & 33.3 & 36 \\
\hline & $\mathrm{UC}$ and $\mathrm{W}+$ & 21.33 & 1.729 & 18.2 & 24.2 & 36 \\
\hline & G and $\mathrm{W}+$ & 31.13 & 1.267 & 28.5 & 33.2 & 36 \\
\hline
\end{tabular}

$\mathrm{SD}=$ Standard deviation, $n=$ number of temperature measurements (three measurements for each plot $\times 12$ plots $=36), \mathrm{UC}$ and $\mathrm{W}-=$ under canopy without water supplementation, $\mathrm{UC}$ and $\mathrm{W}+=$ under canopy with water supplementation, $\mathrm{G}$ and $\mathrm{W}-$ = gap without water supplementation, $\mathrm{G}$ and $\mathrm{W}+$ = gap with water supplementation.

Table 7. Soil temperature values for the period when the seed germination of ESP (end of February-March 2010) took place in the plots of each sowing environment in each of the three sites.

\begin{tabular}{ccccccc}
\hline \multirow{2}{*}{ Site } & \multirow{2}{*}{ Sowing Environment } & \multicolumn{5}{c}{ Soil Temperature $\left({ }^{\circ} \mathrm{C}\right)$} \\
\cline { 3 - 7 } & & Mean & SD & Min & Max & $n$ \\
\hline \multirow{2}{*}{ A } & Under canopy (UC) & 18.70 & 0.948 & 17.0 & 21.0 & 72 \\
& Gap (G) & 22.77 & 1.683 & 14.2 & 25.8 & 72 \\
\hline \multirow{2}{*}{ B } & Under canopy (UC) & 20.15 & 0.819 & 18.6 & 23.1 & 72 \\
& Gap (G) & 23.91 & 1.368 & 21.8 & 26.8 & 72 \\
\hline \multirow{2}{*}{ C } & Under canopy (UC) & 20.05 & 0.855 & 18.0 & 22.0 & 72 \\
& Gap (G) & 23.43 & 1.001 & 21.7 & 25.9 & 72 \\
\hline
\end{tabular}

$\mathrm{SD}=$ Standard deviation, $n=$ number of temperature measurements (three measurements for each plot $\times 24$ plots $=72$ ). 


\subsection{Surviving Measurements}

In Figures 2-7, the monthly seedling survival (number of living seedlings) of both sowing periods (LSP and ESP) in the plots of each combination of the two factor levels is presented for each site.

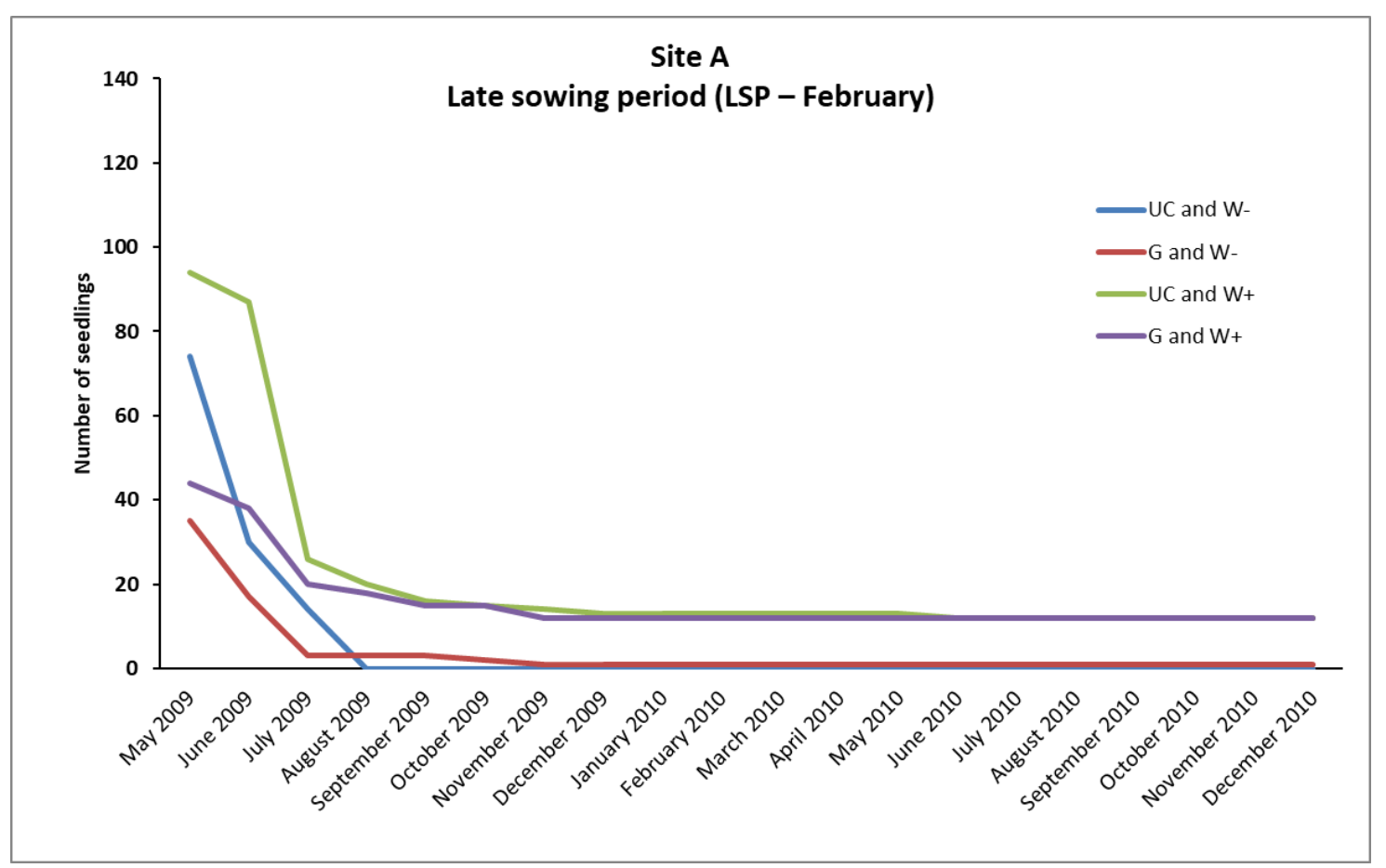

Figure 2. Monthly seedling survival (number of living seedlings) of the February sowing (LSP) in the plots of each combination of the two factor levels in site A for the period May 2009-December 2010 (the May 2009 record shows the number of germinated seeds).

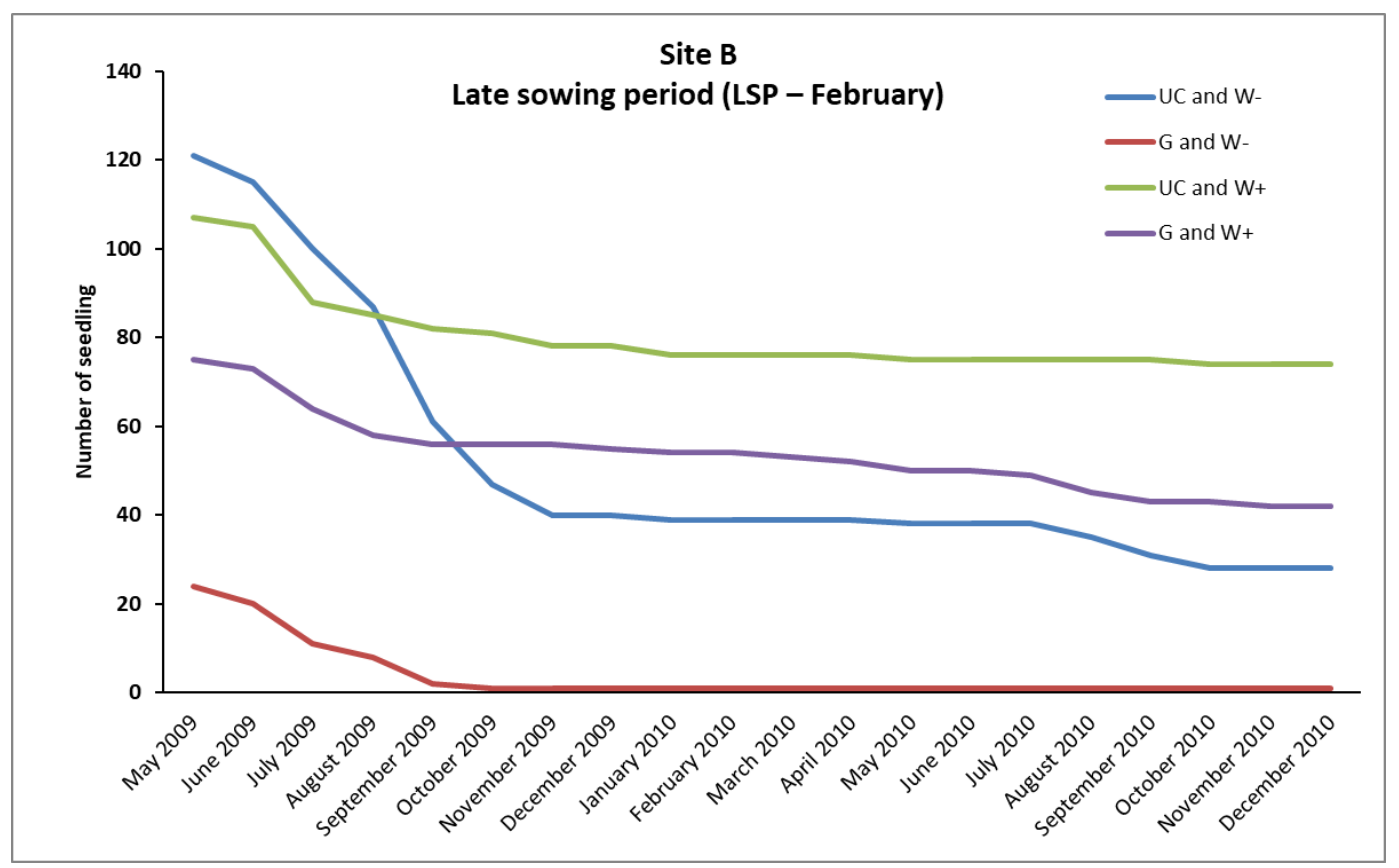

Figure 3. Monthly seedling survival (number of living seedlings) of the February sowing (LSP) in the plots of each combination of the two factor levels in site B for the period May 2009-December 2010 (the May 2009 record shows the number of germinated seeds). 


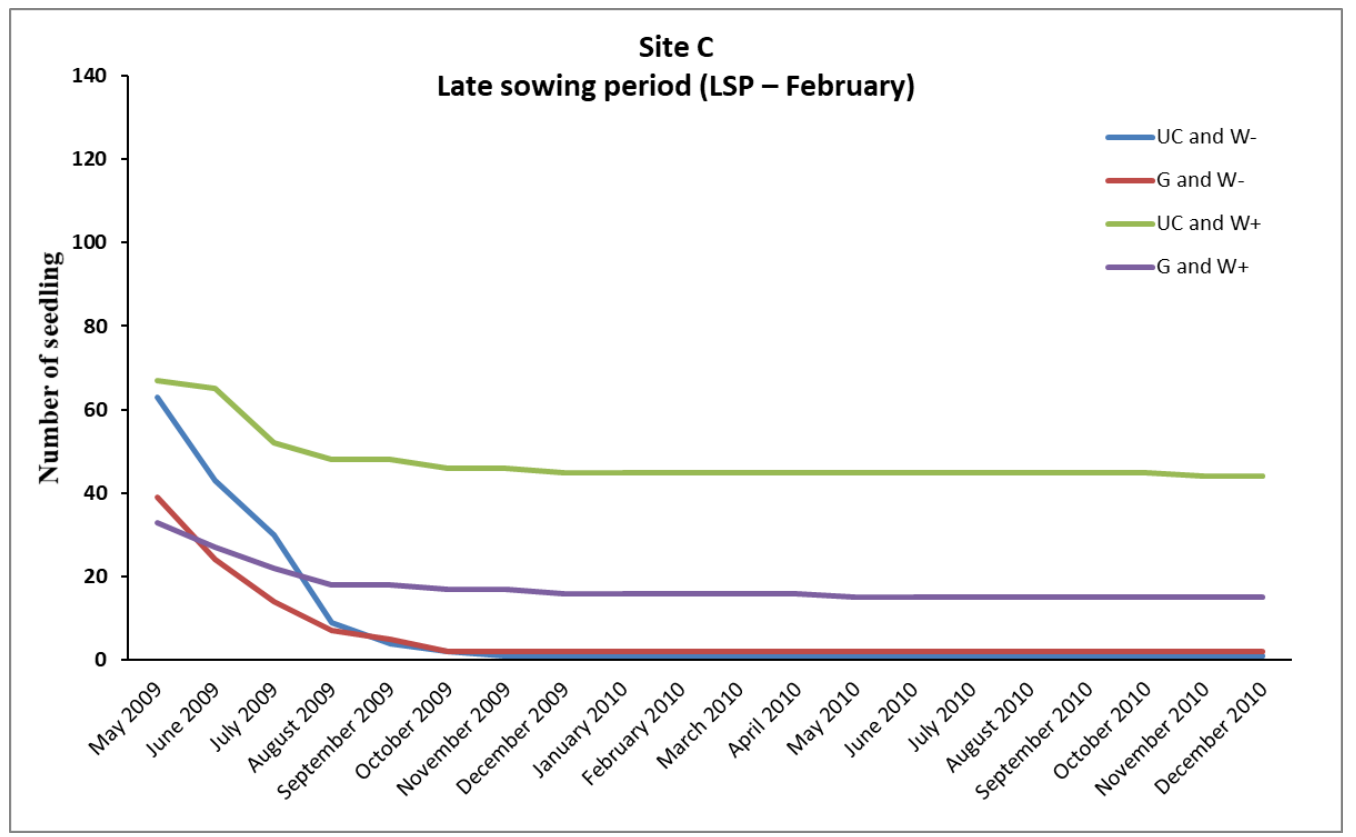

Figure 4. Monthly seedling survival (number of living seedlings) of the February sowing (LSP) in the plots of each combination of the two factor levels in site C for the period May 2009-December 2010 (the May 2009 record shows the number of germinated seeds).

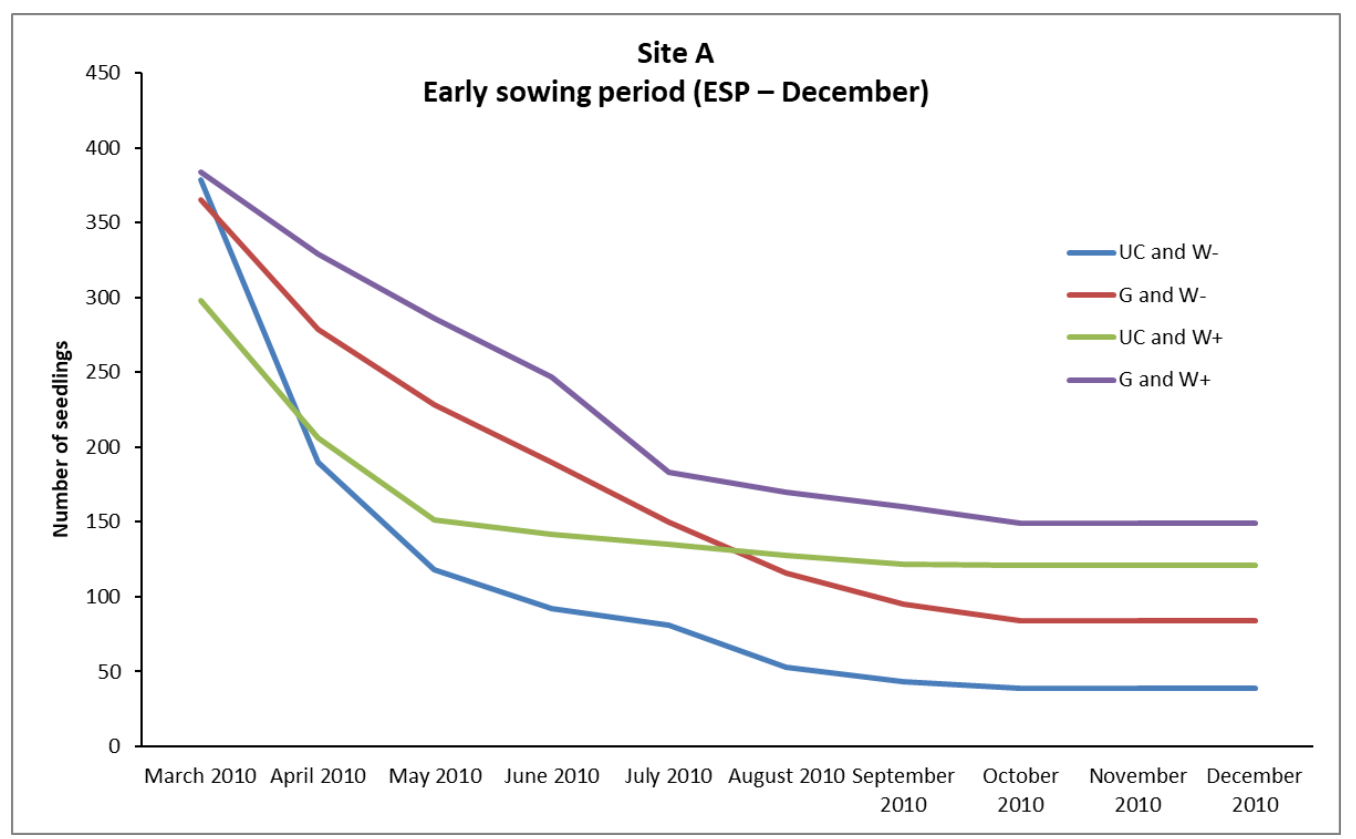

Figure 5. Monthly seedling survival (number of living seedlings) of the December sowing (ESP) in the plots of each combination of the two factor levels in site A for the period March 2010-December 2010 (the March 2010 record shows the number of germinated seeds). 


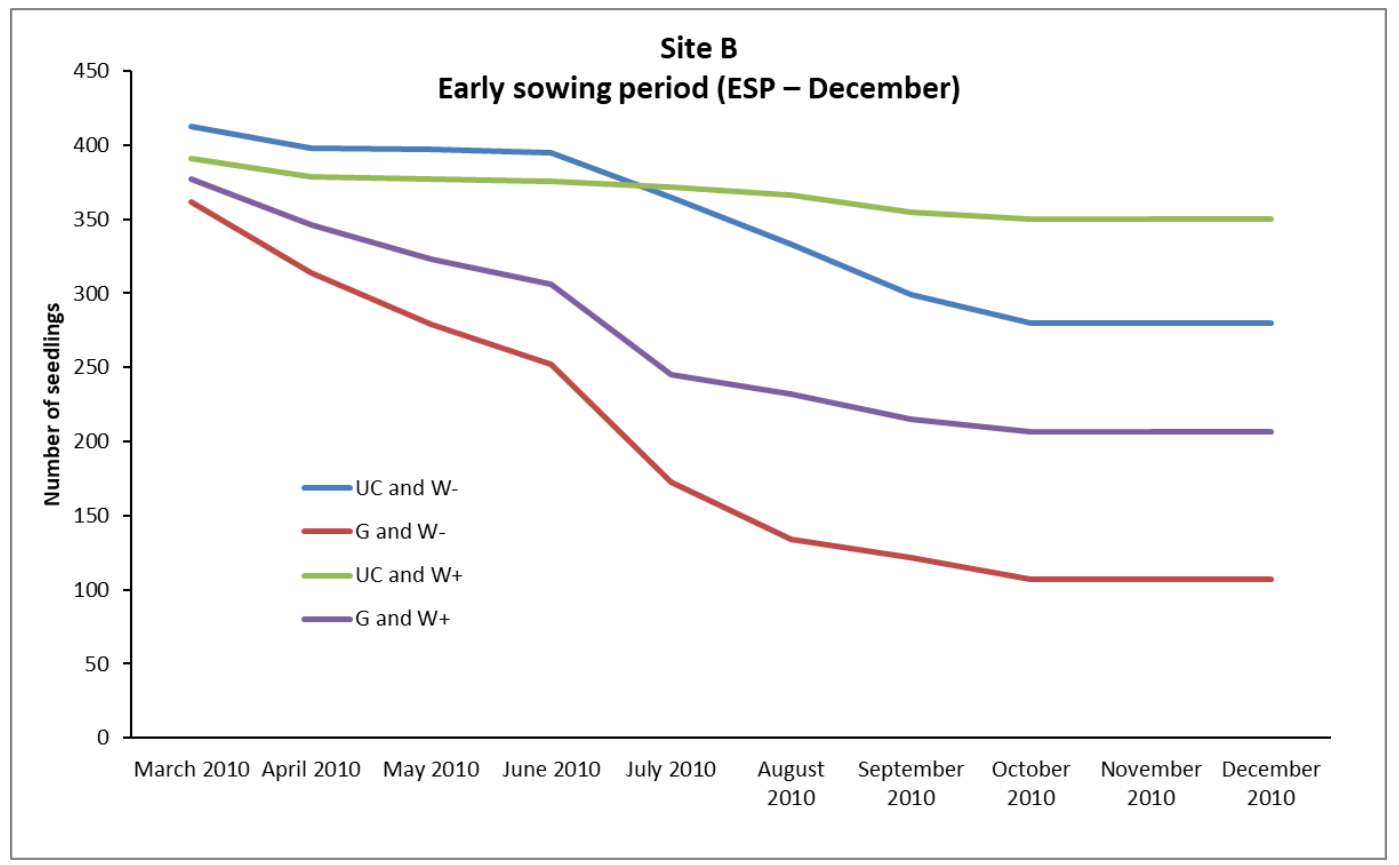

Figure 6. Monthly seedling survival (number of living seedlings) of the December sowing (ESP) in the plots of each combination of the two factor levels in site B for the period March 2010-December 2010 (the March 2010 record shows the number of germinated seeds).

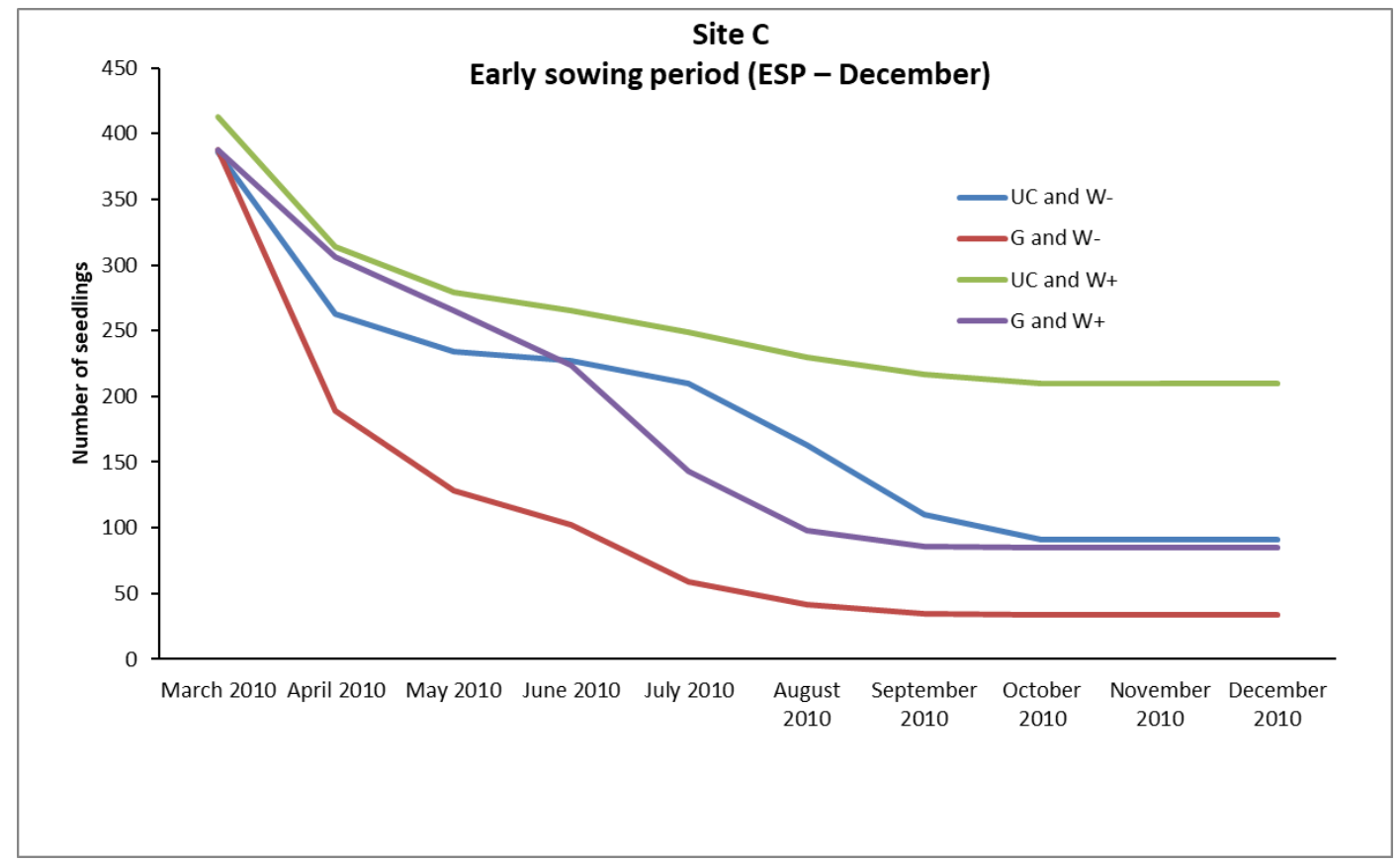

Figure 7. Monthly seedling survival (number of living seedlings) of the December sowing (ESP) in the plots of each combination of the two factor levels in site C for the period March 2010-December 2010 (the March 2010 record shows the number of germinated seeds).

The ANOVA analysis regarding the main effects and the interaction of the two factors, for the ESP (early sowing period) experiment presented the following: (1) for the site A (a) the factor "water supplementation" $(F(1,44)=9.053, p=0.004)$ has a statistically significant influence on the density of the seedlings that survived up to December 2010, (b) the factor "sowing environment" $(F(1,44)=2.233, p=0.142)$ and (c) the interaction of "sowing environment" $x$ "water supplementation" 
$(F(1,44)=0.121, p=0.730)$ have no statistically significant influence on the density of the seedlings that survived up to December 2010, (2) for the site B, (a) the factor "water supplementation" $(F(1,44)=8.514, p=0.006)$ and $(b)$ the factor "sowing environment" $(F(1,44)=29.418, p=0.000)$ have a statistically significant influence on the density of the seedlings that survived up to December 2010, while (c) the interaction of "sowing environment" $\times$ "water supplementation" $(F(1,44)=0,265, p=0,609)$ has no statistically significant influence on the density of the seedlings that survived up to December 2010, (3) for the site C (a) the factor "water supplementation" $(F(1,44)=13.780, p=0.001)$ and (b) the factor "sowing environment" $(F(1,44)=15.794, p=0.000)$ have a statistically significant influence on the density of the seedlings that survived up to December 2010 and (c) the interaction of "sowing environment" $\times$ "water supplementation" $(F(1,44)=2.205, p=0.145)$ has no statistically significant influence on the density of the seedlings that survived up to December 2010.

In sites $B$ and $C$, the $U C$ environment exhibited higher $(p<0.05)$ density of survived seedlings compared to the $\mathrm{G}$ environment, but in site $\mathrm{A}$ there is no difference in the density of survived seedlings between the two sowing environments (Table 8 ). In all sites, $\mathrm{W}+$ plots exhibited higher density of survived seedlings compared to the W- plots (Table 9).

Table 8. Mean density of P. brutia seedlings which survived from the ESP (December 2009) in the plots which were established in the under canopy and in the gap sowing environment (averaged over the two levels of the factor 'water supplementation') in each of the three sites ('sowing environment' main effect).

\begin{tabular}{|c|c|c|c|c|}
\hline \multirow{2}{*}{ Site } & \multirow{2}{*}{ Sowing Environment } & \multicolumn{3}{|c|}{$\begin{array}{l}\text { Seedling Density from the ESF } \\
(n / \text { plot })\end{array}$} \\
\hline & & Mean & SD & $n$ \\
\hline \multirow{2}{*}{$\mathrm{A}$} & Under canopy (UC) & $6.67^{\mathrm{a}}$ & 6.722 & 24 \\
\hline & $\operatorname{Gap}(\mathrm{G})$ & $9.71^{\mathrm{a}}$ & 8.353 & 24 \\
\hline \multirow{2}{*}{ B } & Under canopy (UC) & $26.25^{\mathrm{a}}$ & 8.007 & 24 \\
\hline & Gap $(G)$ & $13.08^{b}$ & 9.908 & 24 \\
\hline \multirow{2}{*}{$\mathrm{C}$} & Under canopy (UC) & $12.54^{\mathrm{a}}$ & 9.036 & 24 \\
\hline & $\operatorname{Gap}(\mathrm{G})$ & $4.96^{\mathrm{b}}$ & 5.684 & 24 \\
\hline
\end{tabular}

In each site, means are statistically significant different, at $p<0.05$ when they share no common letter. The comparison was made using the Bonferroni test. $\mathrm{SD}=$ standard deviation; $n=$ number of plots.

Table 9. Mean density of P. brutia seedlings which survived from the ESP (December 2009) in the plots in which water supplementation was applied and, in the plots, where no watering took place (averaged over the two levels of the factor 'sowing environment') in each of the three sites ('water supplementation' main effect).

\begin{tabular}{ccccc}
\hline \multirow{2}{*}{ Site } & \multirow{2}{*}{ Water Supplementation } & \multicolumn{3}{c}{$\begin{array}{c}\text { Seedling Density from the ESP } \\
(\boldsymbol{n} / \mathbf{\text { plot }})\end{array}$} \\
\cline { 3 - 5 } & & Mean & SD & $n$ \\
\hline \multirow{2}{*}{$\mathrm{A}$} & Water supplementation $(\mathrm{W}+)$ & $11.25^{\mathrm{a}}$ & 8.211 & 24 \\
& No water supplementation $(\mathrm{W}-)$ & $5.13^{\mathrm{b}}$ & 5.728 & 24 \\
\hline \multirow{2}{*}{$\mathrm{B}$} & Water supplementation $(\mathrm{W}+)$ & $23.21^{\mathrm{a}}$ & 10.742 & 24 \\
& No water supplementation (W-) & $16.13^{\mathrm{b}}$ & 10.543 & 24 \\
\hline \multirow{2}{*}{$\mathrm{C}$} & Water supplementation $(\mathrm{W}+)$ & $12.29^{\mathrm{a}}$ & 5.831 & 24 \\
& No water supplementation (W-) & $5.21^{\mathrm{b}}$ & 5.831 & 24 \\
\hline
\end{tabular}

In each site, means are statistically significant different, at $p<0.05$ when they share no common letter. The comparison was made using the Bonferroni test. $\mathrm{SD}=$ standard deviation; $n=$ number of plots.

On the contrary when sowing delayed as in the LSP case, the germination percentages were low and germination began in April and lasted till the middle of May. 
The density of the seedlings that survived up to December 2010 ranged from 3.25 to 12.42 seedlings per plot in site A, while the corresponding values for sites B and C are 8.92 to 29.17 and 2.83 to 17.50 seedlings per plot respectively (Table 10).

Table 10. Mean density of P. brutia seedlings which survived from the ESP (December 2009) in the plots of each of the combinations of the two factor levels in each of the three sites.

\begin{tabular}{|c|c|c|c|c|}
\hline \multirow{2}{*}{ Site } & \multirow{2}{*}{ Combinations of the Two Factor Levels } & \multicolumn{3}{|c|}{ Seedling Density from the ESP $(n /$ plot $)$} \\
\hline & & Mean & SD & $n$ \\
\hline \multirow{4}{*}{ A } & UC and W- & 3.25 & 3.108 & 12 \\
\hline & G and $W-$ & 7.00 & 7.160 & 12 \\
\hline & $\mathrm{UC}$ and $\mathrm{W}+$ & 10.08 & 7.704 & 12 \\
\hline & G and $\mathrm{W}+$ & 12.42 & 8.867 & 12 \\
\hline \multirow{4}{*}{$\mathrm{B}$} & UC and W- & 23.33 & 6.665 & 12 \\
\hline & G and W- & 8.92 & 8.639 & 12 \\
\hline & $\mathrm{UC}$ and $\mathrm{W}+$ & 29.17 & 8.420 & 12 \\
\hline & G and $\mathrm{W}+$ & 17.25 & 9.631 & 12 \\
\hline \multirow{4}{*}{$\mathrm{C}$} & UC and W- & 7.58 & 6.171 & 12 \\
\hline & G and W- & 2.83 & 4.549 & 12 \\
\hline & UC and $W+$ & 17.50 & 8.888 & 12 \\
\hline & G and $\mathrm{W}+$ & 7.08 & 6.082 & 12 \\
\hline
\end{tabular}

$\mathrm{SD}=$ Standard deviation; $n=$ number of plots; $\mathrm{UC}$ and $\mathrm{W}$ - = under canopy without water supplementation; $\mathrm{UC}$ and $\mathrm{W}+=$ under canopy with water supplementation; $\mathrm{G}$ and $\mathrm{W}-$ = gap without water supplementation; $\mathrm{G}$ and $\mathrm{W}+=$ gap with water supplementation.

\section{Discussion}

The germination percentages in the LSP (late sowing period) were very low in all sites (Table 4). On the contrary, in the ESP (early sowing period) the germination percentages were very high in each of the studied sites (Table 5). In both G and UC sowing environments of ESP, the percentages of the germinated seedlings were very high. The difference in the density of germinated seeds between the $G$ and the UC sowing environments in site B (30.79 versus 33.50 germinated seeds per plot), from a practical point of view, is not so important.

It is obvious that the season-period of sowing of P. brutia seeds is very important for seed germination. In ESP a large germination rate was ensured. In that case, the seed germination began at the end of February and lasted up to the end of March. The results of the present study fully agree with what Eron [50] reported for Turkey. He claimed that the germination of P. brutia seeds starts in February at middle elevations (350-650 $\mathrm{m}$ a.s.l.). Moreover, he reported that the germination occurs in November, at lower elevations (250-300 m a.s.l.) and in April at higher elevations (700-800 m a.s.l). This heterogeneity in seed germination indicates different degrees of dormancy among seeds of the same or different populations [12]. This attribute can be explained as an adaptation for seedling survival where seed germination is delayed until well into rainy season when water availability is ensured [20].

In the wider study area of this research, the P. brutia seeds germinate naturally from late February to March (personal observations). No seeds' germination has been observed during October-November. Maybe this happens due to the fact that the dry season, in the studied area, starts at May and lasts until the end of October [33].

Even though P. brutia exhibits a heterogeneity regarding the season of seed germination [12,20], generally the germination in the field takes place successfully during the rain period when the temperatures are also favorable [16,21]. In laboratory conditions, the most favorable temperature range for the germination of $P$. brutia seeds is between $15-20^{\circ} \mathrm{C}$ [51-53]. However, the highest germination rates are reached at $20^{\circ} \mathrm{C}[28,52,54,55]$. 
Soil temperature was one of the factors that played an important role in seed germination in the present study too. The mean soil temperature in the plots that were established the in gap sowing environment $(\mathrm{G})$ during the seed germination period of the LSP in all sites was over $30{ }^{\circ} \mathrm{C}$ (Table 6). This explains the low seed germination in that sowing environment, since the germination of $P$. brutia seeds is dramatically reduced in the temperature of $25^{\circ} \mathrm{C}[28,52]$.

In all plots, the seeds were sowed in a depth of $0.5 \mathrm{~cm}$. As a result, the moisture of the surface soil in the plots of the gap sowing environment where water supplementation was applied every 15 days ( $\mathrm{G}$ and $\mathrm{W}+$ ) evaporated in a short time, due to the relatively high temperatures. This seems to explain why the additional water did not have a positive effect on seed germination, as any adverse effects of high soil temperatures were not mitigated by the watering treatment. Soil moisture is a very important factor that greatly affects the seed germination [56]. If the soil moisture decreases significantly, then the germination of the seeds is either delayed or stopped completely, depending on the duration of the period when the seeds are undergoing this reduction [57]. Boydak et al. [29], who studied the effect of water stress on the germination of seeds of six P. brutia provenances in Turkey found that decreasing water potential also reduced seed germination, showing that water stress inhibits seed germination. The same results were found in a study by Sevik and Erturk [31], which studied the effect of water stress on the germination of seeds of 14 provenances of P. brutia in Turkey.

During the seed germination period of LSP in the plots that were established in the under canopy (UC) sowing environment, the mean soil temperature did not exceed $22{ }^{\circ} \mathrm{C}$ in any of the three sites (Table 6). It has also been shown that the ability to retain soil moisture under shrubs is greater than in bare soil $[58,59]$. Thus, these favorable soil temperatures, in combination with the satisfactory soil surface moisture, both on the surfaces where watering was applied and on those that received only rainwater, led to the germination of a larger number of seeds $(p<0.05)$ in UC compared to G sowing environment (Table 2). On the other hand, shading conditions under tree canopies lead to low germination rates of P. brutia seeds (see [20]). Thus, the late germination of seeds from the LSP and the fact that the period of favorable conditions was short, given that soil temperatures from mid-May onwards become a possible deterrent to the germination of seeds even under the crowns of trees, $[19,33]$ did not allow a large percentage of seeds to germinate in UC sowing environment (as in the ESP).

The germination percentages of $P$. brutia seeds in ESP were very high in both G and UC sowing environments in the three sites (A, B, and C). On the one hand, the early December sowing (ESP) gave substantially longer time with favorable conditions (temperature-Table 7 and moisture) and thus led to high germination rates in both sowing environments. The water from the rainfall of winter months, especially of February 2010 (Figure 1) was stored in soil and probably provided the adequate moisture for seed germination, while evaporation probably was low during the ESP. On the other hand, the seeds that were planted in December experienced low winter temperatures, which is a factor that favors the germination of the seeds when the temperatures start to rise again at the end of winter and the beginning of spring. Skordilis and Thanos [28] report that the seeds of some P. brutia provenances are dormant (see also [20]) and thus their germination is favored by the low winter temperatures, which lead to the breakage of dormancy. As soon as the temperatures become favorable (early spring), there is a strong germination of the seeds of P. brutia. In addition, Escudero et al. [60], who studied the germination of seeds for seven pine species in Spain, found that low temperatures favored the germination of seeds of four pines species-namely, P. halepensis, P. pinaster, and P. pinea-which are low-altitude pines widely distributed in the Mediterranean Basin and P. canariensis which is endemic to Canary Islands. Thus, the above researchers hypothesized that the low temperatures prevailing during the rainy period of winter will favor the germination of seeds in the field of most of the above species.

As mentioned above, in ESP, the germination percentages of $P$. brutia seeds were high even under shade in UC sowing environment (see Vs values in the UC sowing environment in Table 1). This contradicts what Thanos and Skordilis [52] and Thanos [20] state that in shady conditions created under the canopy of trees, the germination of P. brutia seeds is greatly inhibited. The above researchers came to this conclusion, after a study in the laboratory under controlled conditions, which simulated 
the conditions (far-red light) that prevail under the canopy of trees. This, may show a different response to light conditions to seed germination between the different provenances of P. brutia. Probably, the coexistence of all the other favorable conditions mentioned above during the germination of seeds from the December sowing (ESP) outweighed any negative effects that shading can cause and thus the germination rate of the seeds was high, even in the UC sowing environment. Similar results have been found for P. pinea, which is also a light demanding species, where the germination of its seeds was not affected by light conditions, since their germination rates were high, even in conditions of intense shading [61,62].

In the case of P. brutia, seedlings survival from the February (LSP) and December (ESP) sowing, mortality rates were relatively high in $A, B$, and $C$ sites, even in "UC and $\mathrm{W}+$ " and "G and $\mathrm{W}+$ " plots (except from the "UC and $\mathrm{W}+$ " site B in ESP), where water supplementation took place. However, the conditions existing in these plots favored the survival of a larger number of seedlings compared to the plots where no water supplementation took place (Figures 2-7). From the December sowing, from a practical point of view, the number of survived seedlings, in the plots of each combination of the two factor levels, in the three sites can be considered adequate for the successful regeneration of P. brutia. In almost all cases, the mean density of the survived seedlings was over one seedling per $\mathrm{m}^{2}$ (three seedlings per plot) and only in G sowing environment with no water supplementation in site $C$, the mean density of the survived seedlings was 2.83 per plot, marginally lower than one seedling per $\mathrm{m}^{2}$ (Table 10).

However, the majority of seedlings from the February sowing (LSP) that had finally died, died during the first growing season (Figures 2-4). In addition, the majority of seedlings from the December sowing (ESP) that finally died, had died during the period of March-October, while in the following months, until the end of December of the same year, no additional plant deaths were observed (Figures 5-7). These results are in line with the results of several studies that have studied the survival of seedlings of different species and found that the highest mortality rates are observed during the first growing season [19,63,64].

In Mediterranean ecosystems, the lack of water during the summer period is the most important limiting factor, which leads to a reduction in plant survival during the regeneration establishment [64-66].

In the present study, the additional water from the water supplementation treatment was the most important factor that led to the survival of a larger number of seedlings that were established in the December sowing. On the other hand, the lack of water during the dry season was the most important factor that led to the reduction of the survival of seedlings.

The factor "water supplementation" had a statistically significant effect $(p<0.05)$ on the density of seedlings that survived from the December sowing in each of the three sites A, B and C, about one year after germination. In each site the mean seedling density in the plots in which additional water supplementation took place was higher $(p<0.05)$ compared to that of the plots without additional watering (Table 9).

Extreme temperatures, severe drought in summer, and light conditions (radiation) are very important factors, which greatly affect both the establishment and the survival of plants in Mediterranean ecosystems [67]. The above conditions change in space, depending on the environments that exist in an area, thus leading to different relations of competition and facilitation between plants [68-70]. The importance of positive effects between plants varies not only in space but also in time, either due to fluctuations in environmental conditions [71-73] or due to the stage of development (e.g., seedling, sapling, mature plant, etc.) of a plant [74-76].

The "sowing environment" had a very important role in the survival of seedlings from the December sowing (ESP), significantly affecting their density, mainly in the sites B and C. In these sites the UC sowing environment exhibited higher $(p<0.05)$ density of seedlings than the $G$ sowing environment (Table 8). An interesting point is that in both sites $(B, C)$ in the plots that were established under the canopy of pines and did not receive any water supplement (UC and W-plots) survived arithmetically more seedlings than in the plots of the gap that received water supplementation 
(G, $W+$ plots) (Table 10). Seedlings are one of the most vulnerable stages in the life cycle of many plants, as, due to their small size, they cannot cope with many of the adverse environmental conditions $[77,78]$. The relatively low surface soil temperatures that prevail during the growing season in the UC sowing environment in sites B and C $[19,33]$ favored the survival of a larger number of seedlings in this environment. On the contrary, in the G sowing environment, during the growing season, extreme surface soil temperatures prevail $[19,33]$. This resulted in the mortality of a larger number of seedlings in the $G$ sowing environment $[19,34]$.

In particular, in the summer of 2009, in the three sites (A, B, and C) according to Petrou [33] in the UC sowing environments the maximum mean soil temperature (in the depth of $0.5 \mathrm{~cm}$ ) was $40.6{ }^{\circ} \mathrm{C}$. The maximum measured soil temperature was $43.9^{\circ} \mathrm{C}$. For the same period, the maximum mean soil temperature in the $\mathrm{G}$ sowing environments, in the three sites, was over $54{ }^{\circ} \mathrm{C}$, while in sites $\mathrm{B}$ and $\mathrm{C}$ was over $60^{\circ} \mathrm{C}$. The maximum measured soil temperature was $66.4^{\circ} \mathrm{C}$ both in sites B and C [33].

In contrast, in site A, the factor "sowing environment" did not have a significant effect $(p>0.05)$ on the density of seedlings that survived from the ESP and thus there is no difference $(p>0.05)$ in the density of the survived seedlings between the UC and G sowing environments (Table 8). However, numerically, the G sowing environment had a higher density of seedlings than the UC sowing environment, in contrast to what was observed in sites B and C. The fact that soil temperatures during the growing season in the UC sowing environment are more favorable than the G sowing environment, also in the site $\mathrm{A}$ as in the other sites $[19,33]$, did not favor the greater survival of seedlings in the sowing environment UC. The main factor that led to this was obviously the low values of Vs prevailing in the UC sowing environment.

In the UC growing environment of site A the Vs values were up to 0.184 , while in the G sowing environment the Vs values ranged from 0.281 to 0.333 . It seems that the values of Vs in the UC were not favorable for the survival of $P$. brutia seedlings.

Holmgren et al. [79] report that the positive effects of shading on plant survival in drought conditions are more likely to occur in intermediate shading conditions, while in intense shading conditions these positive effects may be lost. They also add that the loss of these positive effects in intense shading and drought conditions under the canopy is more likely to be observed in light demanding species that are drought tolerant than in shade-tolerant species. In experiments in the greenhouse under controlled conditions, it has been shown that in conditions with limited light and water, photosynthesis is directly reduced, thus reducing the carbon dioxide uptake by plants, while negatively affecting their osmotic adjustment, as well as their ability to absorb water [80]. Awada et al. [81] found that the rate of photosynthesis of two-year-old seedlings of P. brutia in shade conditions ( $25 \%$ of full light) was $50 \%$ lower than the rate of photosynthesis of seedlings in full light.

In site A (where the Vs values in UC sowing environment were up to 0.184 ) the UC and W+ plots exhibited arithmetically much higher density of survived seedlings compared to the UC and W-plots. This implies that water supplementation greatly mitigated the competition of mature pines imposed in the established seedlings, thus reducing the negative effects of shading on the survival seedlings in site A.

\section{Conclusions}

The role of the sowing season in the successful germination of seeds in the field was very important. The germination rates of P. brutia seeds from the February sowing (LSP) were very low, while on the contrary from the December sowing (ESP) they were very high. The early sowing in December gave substantially longer time with favorable conditions (temperature and humidity) to the seeds. Regarding the December sowing, the germination rates of P. brutia seeds were very high both in the UC sowing environment and in the G sowing environment in all studies sites.

Most of the seedlings from the February and December sowing which had finally died, died during the first growing season. The lack of water during the dry season was the most important factor that led to the reduction of the survival of seedlings. 
From the December sowing, from a practical point of view, the number of seedlings that survived in the plots of each combination of the two factor levels, in the three sites can be considered adequate for the successful regeneration of P. brutia.

Facilitation is one of the main factors that determines the successful establishment and survival of P. brutia seedlings in middle elevations of central Cyprus.

In the middle elevations of central Cyprus and in analogous ecological environments sowing of P. brutia, seeds can be an option for the artificial regeneration of the species stands. The sowing has to be applied during December under rather open canopy. In particular the Vs values have to be well over 0.19 up to 0.30 . Also, watering has to be applied at least for the first two years after seeding in order an adequate survival percentage of seedlings to be achieved. In a few years after seed sowing, cuttings have to be done in order to supply seedlings with more light which is essential for the growth of a light demanding species.

Moreover, in the middle elevation of central Cyprus and in analogous ecological environments, for natural regeneration process of $P$. brutia stands using the shelterwood silvicultural system, the seeding cutting has to open the canopy at such levels where the Vs values are well over 0.19 (up to 0.30) in order for the light conditions not to prohibit seed germination.

Author Contributions: Conceptualization, P.P. and E.M.; Methodology, P.P. and E.M.; Data curation, P.P.; Writing —original draft preparation, P.P.; Writing—review and editing; E.M., Supervision, E.M. All authors have read and agreed to the published version of the manuscript.

Funding: There is no funding.

Acknowledgments: The authors wish to thank the Department of Forests (Cyprus), for its support.

Conflicts of Interest: The authors declare no conflict of interest.

\section{References}

1. Panetsos, C.P. Monograph of Pinus halepensis and Pinus brutia. Ann. For. 1981, 9, 39-77.

2. Athanasiadis, N. Forest Botany, Part II; Giahoudis-Giapoulis: Thessaloniki, Greece, 1986; p. 309.

3. Quézel, P. Taxonomy and biogeography of Mediterranean pines (Pinus halepensis and P. brutia). In Ecology, Biogeography and Management of Pinus halepensis and P. brutia forest Ecosystems in the Mediterranean Basin; Ne'eman, G., Trabaud, L., Eds.; Backhuys Publishers: Leiden, The Netherlands, 2000; pp. 1-12.

4. Meikle, D.R. Flora of Cyprus; Bentham-Moxon Trust Royal Botanic Gardens Kew: Richmond, UK, 1977; Volume I, p. 832.

5. Pantelas, V. The forest of brutia pine in Cyprus. Options Mediterr. Ser. Stud. 1986, 1, 43-46.

6. Tsintidis, T.; Hadjikyriakos, G.N.; Christodoulou, C.S. Trees and Shrubs in Cyprus; Cyprus Forest Association: Nicosia, Cyprus, 2002; p. 442.

7. Eliades, N.G.H.; Aravanopoulos, F.A.; Christou, A.K. Mediterranean Islands Hosting Marginal and Peripheral Forest Tree Populations: The Case of Pinus brutia Ten. in Cyprus. Forests 2018, 9, 514. [CrossRef]

8. Kitikidou, K.; Petrou, P.; Milios, E. Dominant height growth and site index curves for Calabrian pine (Pinus brutia Ten.) in central Cyprus. Renew. Sust. Energ. Rev. 2012, 16, 1323-1329. [CrossRef]

9. Doukalianou, F.; Radoglou, K.; Agnelli, A.E.; Kitikidou, K.; Milios, E.; Orfanoudakis, M.; Lagomarsino, A. Annual Greenhouse-Gas Emissions from Forest Soil of a Peri-Urban Conifer Forest in Greece under Different Thinning Intensities and Their Climate-Change Mitigation Potential. For. Sci. 2019, 65, 387-400. [CrossRef]

10. Mazza, G.; Angelli, A.E.; Cantiani, P.; Chiavetta, U.; Doukalianou, F.; Kitikidou, K.; Milios, E.; Orfanoudakis, M.; Radoglou, K.; Lagomarsino, A. Short term effects of thinning on soil CO2, N2O and CH4 fluxes in Mediterranean forest ecosystems. Sci. Total Environ. 2019, 651, 713-724. [CrossRef] [PubMed]

11. Milios, E.; Kitikidou, K.; Radoglou, K. New Silvicultural Treatments for Conifer Peri-Urban Forests Having Broadleaves in the Understory-The First Application in the Peri-Urban of Xanthi in Northeastern Greece. South East Eur. For. 2019, 10, 107-116. [CrossRef]

12. Boydak, M. Silvicultural characteristics and natural regeneration of Pinus brutia Ten.-A review. Plant Ecol. 2004, 171, 153-163. [CrossRef] 
13. Eliades, M.; Bruggeman, A.; Djuma, H.; Lubczynski, M.W. Tree water dynamics in a semi-arid, Pinus brutia forest. Water 2018, 10, 1039. [CrossRef]

14. Thanos, C.A.; Daskalakou, E.N. Reproduction in Pinus halepensis and P. brutia. In Ecology, Biogeography and Management of Pinus halepensis and P. brutia forest Ecosystems in the Mediterranean Basin; Ne'eman, G., Trabaud, L., Eds.; Backhuys Publishers: Leiden, The Netherlands, 2000; pp. 79-90.

15. Thanos, C.A.; Marcou, S. Post-fire regeneration in Pinus brutia forest ecosystems of Samos Island (Greece): 6 years after. Acta Oecol. 1991, 12, 633-642.

16. Thanos, C.A.; Marcou, S.; Christodoulakis, D.; Yannitsaros, A. Early post-fire regeneration in Pinus brutia forest ecosystems of Samos island (Greece). Acta Oecol. Oecol. Plant 1989, 10, 79-94.

17. Thanos, C.A. Fire effects on forest vegetation, the case of Mediterranean pine forests in Greece. In Wildfire Management; Eftichidis, G., Balabanis, P., Ghazi, A., Eds.; Algosystems \& European Commission DGXII: Athens, Greece, 1999; pp. 323-336.

18. Radoglou, K.; Christodoulou, A. Comparative research of natural regeneration of Pinus brutia forests of Cyprus and Greece. In Scientific and technological program of Greece-Cyprus cooperation 1996-1998 (Final report). N.AG.R.E.F.; Forestry Department of Cyprus: Nicosia, Cyprus, 1998.

19. Petrou, P.; Milios, E. Establishment and survival of Pinus brutia Ten. seedlings over the first growing season in abandoned fields in central Cyprus. Plant Biosyst. 2012, 146, 522-533.

20. Thanos, C.A. Ecophysiology of seed germination in Pinus halepensis and P. brutia. In Ecology, Biogeography and Management of Pinus halepensis and P. brutia forest Ecosystems in the Mediterranean Basin; Ne'eman, G., Trabaud, L., Eds.; Backhuys Publishers: Leiden, The Netherlands, 2000; pp. 37-50.

21. Thanos, C.A.; Doussi, M. Post-fire regeneration of Pinus brutia forests In Ecology, Biogeography and Management of Pinus halepensis and P. brutia forest Ecosystems in the Mediterranean Basin; Ne'eman, G., Trabaud, L., Eds.; Backhuys Publishers: Leiden, The Netherlands, 2000; pp. 291-301.

22. Zou, C.B.; Barnes, P.W.; Archer, S.; McMurtry, C.R. Soil moisture redistribution as a mechanism of facilitation in savanna tree-shrub clusters. Oecologia 2005, 145, 32-40. [CrossRef] [PubMed]

23. Cheng, D.L.; Wang, G.X.; Chen, B.M.; Wei, X.P. Positive interactions: Crucial organizers in a plant community. J. Integr. Plant Biol. 2006, 48, 128-136. [CrossRef]

24. Smit, C.; Den Ouden, J.; Diaz, M. Facilitation of Quercus ilex recruitment by shrubs in Mediterranean open woodlands. J. Veg. Sci. 2008, 19, 193-200. [CrossRef]

25. O’Brien, M.J.; de Menezes, L.F.T.; Bråthen, K.A.; Losapio, G.; Pugnaire, F.I. Facilitation mediates species presence beyond their environmental optimum. Perspect. Plant Ecol. Evol. Syst. 2019, 38, 24-30. [CrossRef]

26. Milios, E. Facilitation process and sprouting ability as silvicultural tools in the frame of climate change. In Proceedings of the Plenary Lectures of the International Scientific Conference: Forest Ecosystems and Climate Changes, Belgrade, Serbia, 9-10 March 2010; Ljubinko, R., Ed.; Institute of Forestry Belgrade: Belgrade, Serbia, 2010; pp. 137-142.

27. Manso, R.; Calama, R.; Madrigal, G.; Pardos, M. A Silviculture oriented spatio-temporal model for germination in Pinus pinea L. in the Spanish Northern Plateau based on a direct seeding experiment. Eur. J. For. Res. 2013, 132, 969-982. [CrossRef]

28. Skordilis, A.; Thanos, C.A. Seed stratification and germination strategy in the Mediterranean pines Pinus brutia and P. halepensis. Seed Sci. Res. 1995, 5, 151-160. [CrossRef]

29. Boydak, M.; Dirik, H.; Tilki, F.; Çalıkoglu, M. Effect of water stress on germination of six provenances of Pinus brutia seeds from different bioclimatic zones of Turkey. Turk. J. Agric. For. 2003, 27, 91-97.

30. Ahmadlou, F.; Tabari, K.S.M.; Ahmad, R.; Hamed, Y. Study of seed germination and seedling survival of Pinus brutia Ten. in different soils of nursery. Wood Sci. Technol. 2009, 16, 61-76.

31. Sevik, H.; Erturk, N. Effects of drought stress on germination in fourteen provenances of Pinus brutia Ten. seeds in Turkey. Turk. J. Agriculure Food Sci. Technol. 2014, 3, 294-299. [CrossRef]

32. Geological Survey Department of Cyprus. Geological Map of Cyprus; Revised ed.; Press and Information Office: Nicosia, Cyprus, 1995.

33. Petrou, P. Regeneration, Growth and Structure of Calabrian Pine (Pinus brutia Ten.) Stands in the Middle Elevations of Central Cyprus. Ph.D. Thesis, Department of Forestry and Management of the Environment and Natural Resources, Democritus University of Thrace Orestiada, Orestiada, Greece, 2015.

34. Dafis, S. Forest Ecology; Giahoudis-Giapoulis: Thessaloniki, Greece, 1986; p. 443. 
35. Milios, E. Dynamics and Evaluation of the Rhodope Mixed Stands in the Region of Xanthi. Ph.D. Thesis, Faculty of Forestry and Natural Environment, Aristotle University of Thessaloniki, Thessaloniki, Greece, 2000.

36. Adamopoulos, S.; Milios, E.; Doganos, D.; Bistinas, I. Ring width, latewood proportion and dry density in stems of Pinus brutia Ten. Eur. J. Wood Prod. 2009, 67, 471-477. [CrossRef]

37. Papalexandris, C.; Milios, E. Analysis of natural Fagus sylvatica L. s.l. regeneration in low elevation stands located in the central part of Evros region in the Northeast of Greece. Is sprout origin regeneration significant for the species maintenance? Plant Biosyst. 2010, 44, 784-792. [CrossRef]

38. Stampoulidis, A.; Milios, E.; Kitikidou, K. The regeneration of pure Juniperus excelsa Bieb. stands in Pespa National Park in Greece. Sumar. List 2013, 137, 163-172.

39. Smith, D.M.; Larson, B.C.; Kelty, M.J.; Ashton, P.M.S. The practice of silviculture. In Applied Forest Ecology; John Wiley \& Sons, Inc.: New York, NY, USA, 1997; p. 537.

40. Husch, B.; Miller, C.I.; Beers, T.W. Forest Mensuration; John Willey \& Sons, Inc.: New York, NY, USA, $1982 ;$ p. 402.

41. Delta-T Devices Ltd. HemiView User Manual; Delta-T Devices Ltd.: Cambridge, UK, 1999; p. 79.

42. Hale, S.E. Light regime beneath Sitka spruce plantations in northern Britain: Preliminary results. For. Ecol. Manag. 2001, 151, 61-66. [CrossRef]

43. Montgomery, R.A. Effects of understory foliage on patterns of light attenuation near the forest floor. Biotropica 2004, 36, 33. [CrossRef]

44. Fenner, M.; Thompson, K. The Ecology of Seeds; Cambridge University Press: New York, NY, USA, $2005 ;$ p. 260.

45. Gomez, K.A.; Gomez, A.A. Statistical Procedures for Agricultural Research, 2nd ed.; John Wiley \& Sons, Inc.: New York, NY, USA, 1984; p. 680.

46. Girden, E.R. ANOVA: Repeated Measures, Sage University Papers Series on Quantitative Application on the Social Sciences, No 07-08; Sage Publications: Newbury Park, CA, USA, 1992; p. 77.

47. Klockars, A.L.; Sax, G. Multiple Comparisons. Sage University, Paper series on Quantitative Application in the Social Sciences; No. 07-061; Sage Publications: Newbury Park, CA, USA, 1986; p. 97.

48. Toothaker, L.E. Multiple Comparison Procedures. Sage University, Paper series on Quantitative Application in the Social Sciences; No. 07-089; Sage Publications: Newbury Part, CA, USA, 1993; p. 96.

49. IBM Corp. Released IBM SPSS Statistics for Windows, Version 21.0. Armonk; IBM Corp: New York, NY, USA, 2012.

50. Eron, Z. Ecological factors restricting the regeneration of Pinus brutia in Turkey. Ecol. Mediterr. 1987, 13, 57-67. [CrossRef]

51. Isik, K. Altitudinal variation in Pinus brutia Ten.: Seed and seedling characteristics. Silvae Genet. 1986, 35, 58-67.

52. Thanos, C.A.; Skordilis, A. The effects of light, temperature and osmotic stress on the germination of Pinus halepensis and P. brutia seeds. Seed Sci. Technol. 1987, 15, 163-174.

53. Skordilis, A. Seed Germination and Seedling Development in Pinus halepensis and P. brutia. Physiologica1 and Ecologica1 Approach. Ph.D. Thesis, Department of Biology, University of Athens, Athens, Greek, 1992.

54. Tilki, F.; Dirik, H. Seed germination of three provenances of Pinus brutia (Ten.) as influenced by stratification, temperature and water stress. J. Environ. Biol. 2007, 28, 133-136.

55. Cetin, B.; Boydak, M. The effect of heating process on Turkish red pine (Pinus brutia Ten.) seeds. Düzce Üniversitesi Orman Fakültesi Orman. Derg. 2013, 9, 43-54.

56. Kramer, P.J.; Kozlowski, T.T. Physiology of Woody Plants; Academic Press: New York, NY, USA, $1979 ;$ p. 811.

57. Hegarty, T.W. The physiology of seed hydration and dehydration, and the relation between water stress and control of germination: A review. Plant Cell Environ. 1978, 1, 101-109. [CrossRef]

58. Joffre, R.; Rambal, S. Soil water improvement by trees in the rangelands of southern Spain. Acta Oecol. 1988, 9, 405-422.

59. Pugnaire, F.I.; Haase, P.; Puigdefábregas, J. Facilitation between higher plant species in a semiarid environment. Ecology 1996, 77, 1420-1426. [CrossRef]

60. Escudero, A.; Perez-Garcia, F.; Luzurlaga, A.L. Effects of lights, temperature and population variability on the germination of seven Spanish pines. Seed Sci. Res. 2002, 12, 261-271. [CrossRef]

61. Ganatsas, P.; Tsakaldimi, M. Effect of light conditions and salinity on germination behaviour and early growth of umbrella pine (Pinus pinea L.) seed. J. Hortic. Sci. Biotechnol. 2007, 82, 605-610. [CrossRef]

62. Adili, B.; Hedi El Aouni, M.; Balandier, P. Unravelling the influence of light and understorey vegetation on Pinus pinea natural regeneration. Forestry 2013, 86, 297-304. [CrossRef] 
63. Castro, J.; Zamora, R.; Hodar, J.A.; Gomez, J.M. Seedling establishment of a boreal tree species (Pinus sylvestris) at its southernmost distribution limit: Consequences of being in a marginal Mediterranean habitat. J. Ecol. 2004, 92, 266-277. [CrossRef]

64. Gimeno, E.T.; Escudero, A.; Delgado, A.; Valladares, F. Previous Land Use Alters the Effect of Climate Change and Facilitation on Expanding Woodlands of Spanish Juniper. Ecosystems 2012, 15, 564-579. [CrossRef]

65. Gomez-Aparicio, L.; Zamora, R.; Gomez, J.M.; Hodar, J.A.; Castro, J.; Baraza, E. Applying plant facilitation to forest restoration: A meta-analysis of the use of shrubs as nurse plants. Ecol. Appl. 2004, 14, 1128-1138. [CrossRef]

66. Sanchez-Gomez, D.; Zavala, M.A.; Valladares, F. Seedling survival responses to irradiance are differentially influenced by low-water availability in four tree species of the Iberian cool temperate-Mediterranean ecotone. Acta Oecol. 2006, 30, 322-332. [CrossRef]

67. Puerta-Pinero, C.; Gomez, J.M.; Vallardes, F. Irradiance and oak seedling survival and growth in a heterogeneous environment. For. Ecol. Manag. 2007, 242, 242-469. [CrossRef]

68. Aguiar, M.R.; Soriano, A.; Sala, O.E. Competition and facilitation in the recruitment of seedlings in Patagonian steppe. Funct. Ecol. 1992, 6, 66-70. [CrossRef]

69. Aguiar, M.R.; Sala, O.E. Competition, facilitation, seed distribution and the origin of patches in a Patagonian steppe. Oikos 1994, 70, 26-34. [CrossRef]

70. Facelli, J.M.; Temby, A.M. Multiple effects of shrubs on annual plant communities in arid lands of South Australia. Austral. Ecol. 2002, 27, 422-432. [CrossRef]

71. Tielbörger, K.; Kadmon, R. Temporal environmental variation tips the balance between facilitation and interference in desert plants. Ecology 2000, 81, 1544-1553. [CrossRef]

72. Schenk, H.J.; Holzapfel, C.; Hamilton, J.G.; Mahall, B.E. Spatial ecology of a small desert shrub on adjacent geological substrates. J. Ecol. 2003, 91, 383-395. [CrossRef]

73. Armas, C.; Pugnaire, F.I. Plant interactions govern population dynamics in a semi-arid plant community. J. Ecol. 2005, 93, 978-989. [CrossRef]

74. Rousset, O.; Lepart, J. Positive and negative interactions at different life stages of a colonizing species (Quercus humilis). J. Ecol. 2000, 88, 401-412. [CrossRef]

75. Sthultz, C.M.; Gehring, C.A.; Whitham, T.G. Shifts from competition to facilitation between a foundation tree and a pioneer shrub across spatial and temporal scales in a semiarid woodland. New Phytol. 2007,173, 135-145. [CrossRef]

76. Muhamed, H. Spatial distribution and association patterns of Pinus brutia Ten. regeneration. Austrian J. For. Sci. 2019, 2, 141-172.

77. Ibanez, I.; Schupp, E.W. Positive and negative interactions between environmental conditions affecting Cercocarpus ledifolius survival. Oecologia 2001, 129, 543-550. [CrossRef] [PubMed]

78. Silvertown, J.W.; Charlesworth, D. Introduction to Plant Population Biology; Blackwell Science: New York, NY, USA, 2001; p. 347.

79. Holmgren, M.; Gomez-Aparicio, L.; Luis Quero, J.; Valladares, F. Non-linear effects of drought under shade: Reconciling physiological and ecological models in plant communities. Oecologia 2011, 169, 293-305. [CrossRef] [PubMed]

80. Aranda, I.; Pardos, M.; Puertolas, J.; Jimenez, M.D.; Pardos, J.A. Water-use efficiency in cork oak (Quercus suber) is modified by the interaction of water and light availabilities. Tree Physiol. 2007, 27, 671-677. [CrossRef]

81. Awada, T.; Radoglou, K.; Fotelli, M.; Constantinidou, I.A.H. Ecophysiology of seedlings of three Mediterranean pine species in contrasting light regimes. Tree Physiol. 2003, 23, 33-41. [CrossRef]

Publisher's Note: MDPI stays neutral with regard to jurisdictional claims in published maps and institutional affiliations. 